\title{
ПОНЯТТЯ ТА ЗАГАЛЬНА ХАРАКТЕРИСТИКА СПЕЦІАЛЬНИХ ТЕХНІЧНИХ ЗАСОБІВ НЕГЛАСНОГО ОТРИМАННЯ ІНФОРМАЦІЇ ПІД ЧАС ПРОВЕДЕННЯ НЕГЛАСНИХ СЛІДЧИХ (РОЗШУКОВИХ) ДІЙ
}

Виходець Ю. 0.

\begin{abstract}
У статmі проаналізовано проблеми наукового обгрунтування визначення спеціальних технічних засобів негласного отримання інформації під час проведення негласних слідчих (розшукових) дій, правомірність і вимоги до порядку їх застосування для отримання органами досудового розслідування доказів. Проаналізовано особливі вимоги до спеціальних технічних засобів негласного отримання інформаціі, залежно від мети проведення негласних слідчих (розшукових) дій, що зумовлені негласністю застосування, необхід ністю дотримання конституційних прав учасників кримінального провадження.
\end{abstract}

Ключові слова: досудове розслідування, спеціальні технічні засоби негласного отримання інформації, негласні слідчі (розшукові) діі.

В статье проанализированы проблемы научного обоснования определения специальных технических средств негласного получения информации при проведении негласных следственных (разыскных) действий, правомерность и требования к порядку их применения для получения органами досудебного расследования доказательств. Проанализированы особые требования к специальным техническим средствам негласного получения информации, в зависимости от цели проведения негласных следственных (разыскных) действий, обусловленных негласностью применения, необходимостью соблюдения конституционных прав участников уголовного производства.

Ключевые слова: досудебное расследование, специальные технические средства негласного получения информации, негласные следственные (разыскные) действия.

Vykhodets Yu. 0. Concepts and general characteristics of special technical means of unauthorized receipt of information in conduct of unauthorized investigators (search)

The article analyzes the problems of scientific substantiation of the definition of special technical means of secret information retrieval when conducting secret investigative (investigative) actions, legitimacy and requirements to the order of their application for obtaining by bodies of pre-trial investigation of evidence. Attention is drawn to the ambiguity of the concept of "technical means" used in law enforcement activities, both in scientific research and at the legislative level. In particular, it is possible to come across such concepts as "technical means", "forensic equipment", "special equipment", "means of special equipment for the fight against crime", "special means", "special technical means", "operative equipment", "means of secret information", etc. However, virtually every one of them does not have a clear definition and indication of what "means" are concerned.

Based on the analysis of scientific literature and regulatory acts of different agencies, it was found that among the terminological phrases that use the above terms in the field of law

(с) Виходець Ю. О., 2020 enforcement, the most common received: "special equipment", "special technical means", "operative- technical means", "scientific and technical means" and their derivatives.

Attention is drawn to the special requirements for special technical means of unspoken information, depending on the purpose of conducting unspoken investigative (search) actions, which are caused by the unspoken application, the need to observe the constitutional rights of participants in criminal proceedings.

The notion of special technical means of unofficial retrieval of information in carrying out unspoken investigative (investigative) actions is formulated, which is understood as a set of technical, software-technical and software tools, devices, automated systems, substances and scientifically-substantiated methods and tactical techniques of hidden use of them specially adapted solving problems of criminal procedure activity used by authorized persons in carrying out unspoken investigative (search) actions for negl the receipt of information and meet the requirements that determine its ability to be used with strict observance of the principle of legality.

Key words: pre-trial investigation, special technical means of silent retrieval of information, unspoken investigators (investigative) actions.

Постановка проблеми та її актуальність. Як свідчить слідчо-оперативна практика, нині діяльність правоохоронних органів із розкриття та розслідування злочинів здійснюється в умовах зростання інформаційно-технічної протидії з боку злочинних формувань [1, с. 9]. Зусилля органів досудового розслідування нерідко не дають результатів через те, що кримінальні елементи за допомогою новітніх технічних засобів негласного отримання інформації легко отримують необхідні відомості про конкретну спрямованість діяльності правоохоронних органів, без особливих труднощів і небезпеки паралізують їх роботу. Отже, по суті, та боротьба, яку ведуть працівники правоохоронних органів із кримінальним світом, - це насамперед боротьба за інформацію, де виграє той, хто зможе найбільш ефективно отримати та використати свою інформацію. Тому на передній план виходить проблема використання науково-технічних засобів із метою виявлення, збирання, фіксації, дослідження й використання фактичних даних щодо обставин кримінального правопорушення під час проведення досудового розслідування як один із визначних чинників підвищення ефективності діяльності з розкриття та розслідування злочинів.

Застосування технічних засобів має місце і під час проведення відповідних негласних слідчих (розшукових) дій (далі - НСРД). Адже підвищенні ефективності й результативності НСРД у разі їх проведення неможливе без використання відповідних засобів. Зокрема це стосується техніки, яка використовується для прове- 
дення конкретних НСРД. Але законодавець, коли вводив інститут НСРД у кримінальному провадженні, не врахував практичної реалізації їх проведення.

Отже, поняття, зміст, класифікація і підстави застосування спеціальних технічних засобів негласного отримання інформації, що використовуються під час проведення НСРД, мають бути чітко врегульовані юридично. Проте нині правова реґламентації даних засобів діяльності правоохоронних органів $\epsilon$ неповною та суперечливою, що призводить до порушень законності, а інколи і до зловживань з украй шкідливими наслідками [2, с. 13]. Викладене зумовлює актуальність обраної тематики.

Аналіз останніх досліджень і публікацій. Загальні й окремі проблеми застосування науково-технічних засобів проведенні оперативно-розшукових заходів розглядалися В.В. Бірюковим, Д.Д. Бєговим, В.Б. Вишнею, О.Г. Волеводзом, В.І. Гончаренком, Л.І. Громовенко, B.I. Декшне, О.Ф. Долженковим, П.А. Єрмаковим, Ю.Ф. Жаріковим, І.О. Ієрусалимовим, О.О. Пундою, М.В. Салтевським, Е.Ф. Толмачевим, І.Р. Шинкаренком, І.Ф. Хараберюшем, М.І. Хавронюком та багатьма іншими науковцями. Правові особливості використання спеціальних технічних засобів таємного зняття інформації досліджувались у працях П.П. Андрушка, П.С. Берзіна, І.О. Зінченко, В.Д. Камінського, М.В. Карчевського, Д.Ю. Кондратова, І.В. Логінова, С.Я. Лихової, М.І. Мельника, О.В. Обухова й ін.

Однак комплексних наукових досліджень проблематики використання у кримінальному провадженні спеціальних технічних засобів негласного отримання інформації під час проведення негласних слідчих (розшукових) дій дотепер не проводилось. Тож, низка питань, важливих як із позиції доктрини кримінального процесу, так і з погляду правозастосування, залишаються недослідженими, отже, становлять перспективу для наукового пошуку.

Метою статті $\epsilon$ визначення сутності категорії «спеціальні технічні засоби, що використовуються під час проведення негласних слідчих (розшукових) дій», розкриття іï змісту, з формулюванням відповідної дефініції, а також загальне наукове обґрунтування необхідності й ефективності їх застосування в діяльності правоохоронних органів.

Виклад основного матеріалу. Питання засобів, що використовуються під час проведення НСРД, законодавець окремо врегулював у ст. 273 Кримінального процесуального кодесу (далі - КПК) України. Проте аналіз змісту зазначеної норми та практики застосування таких засобів дозволяє стверджувати, що вони не охоплюють сповна тих засобів, що використовуються під час проведення НСРД, а їх реалізація часто виявляється неможливою. Крім того, у багатьох статтях гл. 21 КПК України, де йдеться про негласні слідчі (розшукові) дії, законодавець уживає терміни «технічні та інші засоби», проте не розкриває їхнього смислу і не пропонує змістовного наповнення. Крім того, у науковій літературі неодноразово наголошувалось на тому, що КПК України чітко не визначає питання щодо порядку застосування технічних засобів, які використовуються під час проведення негласних слідчих (розшукових) дій [3, с. 8-9].

НСРД за своїм змістом збігаються з відповідними оперативно-розшуковими заходами (далі - ОРЗ), відрізняються від них лише юридичною формою та колом суб'єктів ініціативи [2, с. 14]. ОРЗ використовуються не для виконання завдань кримінального провадження, а для пошуку і фіксації фактичних даних про злочинні діяння окремих осіб і груп, розвідувально-підривну діяльність спеціальних служб іноземних держав та організацій із метою припинення правопорушень і в інтересах кримінального судочинства, а також отримання інформації в інтересах безпеки громадян, суспільства і держави. Проте, погоджуючись з М.А. Погорецьким та Д.Б. Сергєєвою, зазначимо, що НСРД мають однакову гносеологічну природу, один алгоритм здійснення з однойменними оперативно-розшуковими заходами, передбаченими ст. 8 Закону України «Про оперативно-розшукову діяльність». Вони проводяться із застосуванням тотожних методів пізнання події злочину, в одному режимі таємності [4, с. 138]. Утім, поділяємо думку М.Л. Грібова і зазначимо, незважаючи на принципову ідентичність технічних засобів під час проведення НСРД і ОРД, механічне перенесення до термінологічного апарату кримінального процесу назви «оперативно-технічні засоби» буде некоректним через фактичну юридичну форму дій, що провадяться слідчим, прокурором або, за їх дорученням, уповноваженим оперативним підрозділом [5, с. 155]. Термін «спеціальні технічні засоби» може трактуватися дуже широко, а тому в межах кримінального провадження потребує окремого унормування.

Звернувшись до нормативних і наукових тлумачень, що вживаються у правових документах, які реґламентують питання застосування у кримінальному судочинстві терміна «технічні засоби», спробуємо проаналізувати розуміння таких засобів. Насамперед це зумовлено завданнями та засадами кримінального судочинства, за умови суворого дотримання процесуальної форми, яка не допускає вживання понять, зміст яких не зрозумілий чи їх тлумачення неоднозначне [6, с. 210].

«Засіб» у загальновживаному значенні тлумачиться як спеціальна дія, яка дає можливість здійснити що-небудь, досягти чогось; спосіб, прийом [7, с. 420]. У результаті проведеного аналізу наукових робіт науковців щодо визначення поняття «засіб», ми побачили, що його дослідження переважно здійснювалось у межах щодо оперативно-розшукової діяльності, однак автори по-різному підходять до його визначення.

М.А. Погорецький стверджує, що засобами в оперативно-розшуковій діяльності $\epsilon$ все те, за допомогою чого забезпечується отримання результату ОРД, зокрема й ОР3 [8, с. 171]. Інші науковці поняття засобів тлумачать у більш вузькому розумінні, коли засоби розглядаються як речі матеріального світу, завдяки використанню яких отримують потрібний результат. Такий підхід $\epsilon$ традиційним для наукової та навчальної літератури з питань ОРД. Але нині він зазнає конструктивної критики [9, с. 273]. Проте така критика стосується не розуміння засобу суто як матеріального інструменту досягнення якоїсь ідеальної цілі, а переліку категорій таких матеріальних інструментів.

У дослідженні розуміння засобів ОРД Ю.Ю. Орлов визначив ї як сукупність знаряддя (матеріальний інструментарій) та науково обґрунтованих прийомів його правомірного застосування суб'єктом ОРД для виконання завдань цієї діяльності. Під оперативно-технічними засобами автор розуміє технічні засоби, що мають специфічні конструктивні ознаки або властиво- 
сті, які вказують на їхнє призначення для застосування в ОРД (зокрема, на їхнє призначення для негласного отримання інформації) [10, с. 41].

І.Ф. Хараберюш оперативно-технічні засоби відносить до оперативної техніки, як засіб отримання інформації, визначає їх як сукупність оперативно-технічних засобів та науково обґрунтованих тактичних прийомів, способів та інформаційних технологій, що використовуються із суворим дотриманням законності з метою виконання правоохоронними органами завдань оперативно-розшукової діяльності та кримінального провадження. Оперативно-технічними засобами, відповідно до цього визначення, $\epsilon$ технічні, програмно-технічні та програмні засоби, інформаційні системи, спеціальні пристрої, речовини [11, с. 369]. Технічними засобами негласного отримання інформації можуть бути засоби: загального застосування (пристосовані), загального застосування 3 незначною доробкою (модифіковані) і спеціально розроблені (унікальні). Це також можуть бути програмні або програмно-технічні засоби, запрограмовані для цієї мети й автоматизовані системи. Технічні засоби загального застосування мають широкий спектр використання, окрім оперативно-розшукової діяльності, це криміналістика, слідча діяльність, адміністративна діяльність тощо. Прикладом може слугувати побутова і професійна фото-, відеоапаратура, засоби звукозапису, системи зв'язку, обчислювальна техніка й інші технічні засоби, вироблені для широкого кола споживачів. Особливість цієї групи технічних засобів полягає в тому, що, хоча самі вони не зазнають жодних конструктивних змін, тактика і методика їх застосування залежать від оперативних заходів, у яких застосовано ці технічні засоби [12, с. 79].

За всієї розмаїтості понять щодо визначення засобів, які використовуються правоохоронними органами у кримінальному провадженні й оперативно-розшуковій діяльності, найбільш поширений термін «спеціальна техніка» і похідні від нього (наприклад, «спеціальні технічні засоби», «оперативно-технічні засоби»). Ці терміни в основному вживаються в наукових дослідженнях, навчальній літературі, законодавчих і нормативних актах, що стсоуються відомств, які здійснюють правоохоронну діяльність. Тобто проглядається ухил убік визначення науково-технічних засобів, що використовуються у процесі оперативно-розшукової діяльності, розкритті й розслідуванні злочинів [13, с. 98].

Однак у спеціальній літературі немає єдності поглядів і щодо визначення поняття «спеціальні технічні засоби». О.В. Камінська, П.П. Підюков, Ю.В. Скудар стверджують, що термін «спеціальні технічні засоби», як $\mathrm{i}$ «оперативні» й «оперативно-технічні засоби», походить від термінів «оперативно-розшукові заходи», «оперативно-розшукові дії». Аналіз положень, запропонованих науковцями, свідчить, що спеціальними технічними засобами вони вважають все те, що в теорії ОРД має усталену назву - «оперативно-технічні засоби» [14, с. 193].

На думку М.І. Цимбал, під спеціальними технічними засобами варто розуміти технічні засоби, які призначені, розроблені, пристосовані чи запрограмовані для негласного отримання інформації [15, с. 559].

В.О. Допілка вважає, що спеціальними технічними засобами негласного отримання інформації варто вважати такі пристрої, обладнання, апаратуру тощо, які були спеціально пристосовані (сконструйовані) для негласного отримання інформації (наприклад, технічні засоби для негласного візуального спостереження та документування, технічні засоби негласного прослуховування телефонних розмов) [16, с. 47].

М.І. Хавронюк визначає спеціальні технічні засоби негласного отримання інформації як технічні засоби, устаткування, апаратуру, прилади, пристрої, препарати й інші вироби, спеціально створені, розроблені, модернізовані, запрограмовані або пристосовані для виконання завдань із негласного отримання інформації під час здійснення оперативно-розшукової діяльності [17, с. 296]. Більш широке визначення наводить Н.О. Гуторова: пристрої і прилади для таємного прослуховування і спостереження, зокрема й з використанням аудіо- та відеозапису, кіно- і фотозйомки, оптичних приладів тощо [18, с. 499].

Інші дослідники вважають, що до оперативної техніки (спеціальні технічні засоби) можуть бути віднесені як спеціально виготовлені технічні засоби негласного отримання інформації, так і пристосована побутова техніка, що має можливість негласного отримання інформації [19, с. 52].

Отже, реалізація вимог правоохоронних органів до спеціальних технічних засобів визначає можливість їх використання для вирішення завдань оперативно-розшукової та кримінальної процесуальної діяльності у властивій їм формах та належними методами.

Доречним буде зазначити, що до технічних засобів негласного отримання інформації можна віднести і програмні засоби негласного зняття інформації. Хоча програмні засоби негласного зняття інформації і не виділені як окремий вид спеціальних засобів, а розглядаються як технічні засоби, однак у реаліях сучасних технологій, їхнього стрімкого розвитку, це не цілком правильно. Адже програмний засіб негласного зняття інформації $\epsilon$ не технічним пристроєм, а суто комп'ютерною програмою, яка діє на основі технічного пристрою, що може бути в загальному вжитку. Сама комп'ютерна програма - це набір інструкцій у вигляді слів, цифр, кодів, схем, символів чи в будь-якому іншому вигляді, виражених у формі, придатній для зчитування (комп'ютером), які приводять його в дію для досягнення певної мети або результату [20, с. 168-170]. Ми погоджуємося з думкою С.І. Шитого й І.І. Огороднікової стосовно визначення програмних засобів негласного зняття інформації, як: набору інструкцій у вигляді слів, цифр, кодів, схем, символів чи в будь-якому іншому вигляді, виражених у формі, придатній для зчитування електронно-обчислювальною машиною або комп'ютером, які приводять його в дію для негласного отримання інформації з каналів зв'язку, інших електронно-обчислювальних машин, комп'ютерів, пристроїв із функцією комп'ютера, технічних, електронних або цифрових пристроїв і відповідають критеріям належності до засобів негласного отримання інформації, призначені для використання у прихований спосіб, характерний для оперативно-розшукової, контррозвідувальної або розвідувальної діяльності [21, с. 85].

Отже, більшість науковців сходяться на думці, що спеціальні технічні засоби негласного отримання інформації - це всі вироби, призначенні для негласного отримання інформації, які застосовуються правоохоронними органами для виконання поставлених перед 
ними завдань. Мобільний телефон, фото- та відеокамера, якщо вони використовуються для досягнення цілей проведення ОРЗ чи НСРД, будуть тими засобами, пристроями, за допомогою яких можна негласно отримати інформацію [22]. На наш погляд, під спеціальними технічними засобами варто розуміти апаратні, програмні й апаратно-програмні засоби, призначені для негласного отримання інформації у прихований спосіб та придатні для здійснення оперативно-розшукових заходів і негласних слідчих (розшукових) дій. 3 урахуванням вимог законодавства, остаточний висновок щодо належності/неналежності засобів до спеціальних технічних засобів негласного отримання інформації надає Служба безпеки України (далі - СБУ) [23, с. 41]. Якщо бути точнішими, згідно з положеннями Закону України «Про судову експертизу», судово-експертна діяльність здійснюється спеціалізованими установами, до яких, зокрема, належить і експертна служба СБУ.

3 огляду на вищевикладене, підтримуємо думку О.О. Козенко і зауважимо, що спеціальна техніка - це сукупність технічних засобів, спеціальних пристроїв, речовин і відповідних тактичних прийомів, що використовуються оперативними та слідчими підрозділами, ї співробітниками із суворим дотриманням законодавства під час здійснення оперативно-слідчих заходів із метою запобігання злочинам, кримінальним правопорушенням та іншим проступкам як цивільного, так i адміністративного характеру, а також їх розслідування [24, с. 41].

Висновки. Зазначена проблема пов'язана з розвитком сучасних інформаційних технологій, упровадженням у широкий ужиток новітніх технічних пристроїв, що змінили і далі змінюють спосіб і характер використання спеціальних технічних засобів негласного отримання інформації у кримінальному провадженні, зокрема і під час проведення негласних слідчих (розшукових) дій. А сучасні можливості технічних засобів негласного отримання інформації дозволяють отримати більш широке коло фактичних даних у кримінальному провадженні.

Отже, на підставі наукового обґрунтування необхідності й ефективності використання науково-технічних засобів у діяльності правоохоронних органів можемо зробити висновок, що за цільовим призначенням спеціальні технічні засоби негласного отримання інформації під час проведення негласних слідчих (розшукових) дій $\epsilon$ різновидом технічних засобів, що використовуються у правоохоронній діяльності. Лише технічні засоби негласного отримання інформації, які спеціально пристосовані та/або взагалі відповідають вимогам, що визначають можливість їх використання для вирішення завдань оперативно-розшукової та кримінально-процесуальної діяльності у властивих їм формах та методах, можуть бути віднесені до спеціальних технічних засобів. Тобто технічні засоби негласного отримання інформації, що були виготовлені не для потреб правоохоронних органів, але відповідають зазначеним вимогам, можуть бути віднесені до спеціальних технічних засобів. Проте відсутність єдиного розуміння сутності спеціальних технічних засобів негласного отримання інформації, застосовуваних у сфері кримінального провадження під час проведення негласних слідчих (розшукових) дій, невизначеність їхнього правового статусу та порядку використання у кримінально-процесуальній діяльності спричиняють не тільки нечіткість нормативно-правових формулювань, але й негативно позначаються на якості досудового розслідування та судового розгляду кримінальних проваджень.

На підставі проаналізованих думок учених, з урахуванням нормативної визначеності щодо технічних засобів негласного зняття інформації, пропонуємо таке визначення: спеціальні технічні засоби негласного отримання інформації під час проведення негласних слідчих (розшукових) дій - це сукупність технічних, програмно-технічних та програмних засобів, пристроїв, автоматизованих систем, речовин та науково обґрунтованих способів і тактичних прийомів прихованого їх використання, спеціально пристосованих для вирішення завдань кримінально-процесуальної діяльності, що використовуються уповноваженими особами під час проведення НСРД для негласного отримання інформації та відповідають вимогам, що визначають можливість ï використання із суворим дотриманням принципу законності.

У зв'язку із чим пропонуємо:

окремо виділити і законодавчо закріпити поняття спеціальних технічних засобів негласного отримання інформації шляхом внесення змін у закони України «Про оперативно-розшукову діяльність», «Про Службу безпеки України», «Про інформацію», у положення відповідних постанов Кабінету Міністрів України й інших підзаконних нормативно-правових актів. За основу пропонується взяти визначення, сформульоване автором у статті;

на законодавчому рівні заборонити правоохоронним органам в Україні використання спеціальних технічних засобів негласного отримання інформації, що порушують права людини, окрім як за ухвалою суду і лише у справах, пов'язаних із контррозвідувальною діяльністю або боротьбою з корупцією, шляхом внесення відповідних змін у відповідні закони, положенням такого змісту: «Під час отримання даних під час застосування спеціальних технічних засобів негласного отримання інформації правоохоронним органам вживати заходів щодо охорони та нерозголошення інформації, отриманої за їх допомогою, яка розкривається виключно для виконання обов'язків або задоволення потреб правосуддя. Будь-яке розголошення такої інформації з іншою метою заборонено».

\section{Література}

1. Орлов Ю.Ю. Технічна сторона (основа) оперативно-розшукової діяльності. Спеціальна техніка у правоохоронній діяльності : матеріали III Міжнародної науково-практичної конфереренції, М. Київ, 25-26 жовтня 2007 р. / ред. кол. : О.М. Джужа та ін. Київ, 2007. С. 9-12.

2. Грібов М.Л. Правове регулювання візуального спостереження. Боротьба з організованою злочинністю $i$ корупцією (теорія і практика). 2012. № 1 (27). С. 13-23.

3. Глушков В.О. Актуалізація проблеми вдосконалення законодавства України про оперативно-розшукову діяльність. Актуальні проблеми оперативно-розшукової діяльності правоохоронних органів в сучасних умовах : матеріали Міжвідомчої науково-практичної конференції, 19 травня 2011 р., м. Київ. Київ : Наук.-вид. відділ НА СБ України, 2011. С. 6-11.

4. Погорецький М.А., Сергєєва Д.Б. Негласні слідчі (розшукові) дії та оперативно-розшукові заходи: поняття, сутність і співвідношення. Боротьба з організова- 
ною злочинністю і корупцією (теорія і практика). 2014. № 2 (33). C. 137-141.

5. Грібов М.Л. Засоби, що використовуються під час проведення негласних слідчих (розшукових) дій. Бюлетень Міністерства юстиції України. 2014. № 9. С. 152-158.

6. Шульга Н.В. Використання інноваційних технологій у кримінальному процесі. Науковий вісник публічного та приватного права. 2016. Вип. 6. Т. 2. С. 208-217.

7. Великий тлумачний словник сучасної української мови / уклад. і голов. ред. В.Т. Бусел. Київ ; Ірпінь : Перун, 2009. 1736 с.

8. Погорецький М.А. Функціональне призначення оперативно-розшукової діяльності у кримінальному процесі : монографія. Харків : Арсіс Лтд, 2007. 576 с.

9. Пеньков С.В. Окремі аспекти зарубіжного досвіду застосування оперативної техніки правоохоронними органами. Вісник Луганського державного універcumemy внутрішніх справ імені Е.О. Дідоренка. 2016. Вип. 3. С. 271-280.

10. Орлов Ю.Ю. Застосування оперативної техніки в оперативно-розшуковій діяльності міліції (теорія і практика) : монографія. Київ : Київ. нац. ун-т внутр.справ, 2007. 559 c.

11. Хараберюш І.Ф., Ортинський В.Л., Хараберюш 0.І. Концептуальні та теоретико-прикладні засади оперативно-розшукового забезпечення протидії контрабанді в Україні : монографія. Маріуполь : ППНС, 2017. 476 с.

12. Хараберюш І.Ф. Оперативна техніка як теоретико-прикладна категорія оперативно-розшукової науки. Вісник Маріупольського державного університету. Серія «Право». 2017. Вип. 13. С. 77-82.

13. Безруков Д.В., Хараберюш І.Ф. Особливості використання матеріалів, отриманих засобами спеціальної техніки у досудовому розслідуванні органами внутрішніх справ за новим кримінальним процесуальним законом. Проблеми правознавства та правоохоронної діяльноcmi : збірник наукових праць Донецького юридичного інституту Міністерства внутрішніх справ України. 2013. № 1. С. 96-104.

14. Підюков П.П., Скудар Ю.В., Камінська О.В. Використання у кримінальному судочинстві спеціальних технічних засобів під час здійснення негласних слідчих (розшукових) дій: історія, сучасний стан і перспективи. Наука і правоохоронна діяльність. 2013. № 1 (19). С. 190-194.
15. Цимбал M.І. Питання профілактики незаконного поводження із спеціальними технічними засобами негласного отримання інформації. Актуальні проблеми держави і права. 2012. Вип. 64. С. 558-563.

16. Допілка В.О. Контрабанда спеціальних технічних засобів негласного отримання інформації. Митна справа. 2012. № 2 (80). С. 45-49.

17. Науково-практичний коментар Кримінального кодексу України / за ред. М.І. Мельника, М.І. Хавронюка. 5-те вид., переробл. та доповн. Київ : Юридична думка, 2008. 1765 c.

18. Кримінальне право України: Особлива частина : підручник / за ред. В.В. Сташиса, В.Я. Тація. 4-те вид., переробл. і допов. Харків : Право, 2010. 1274 с.

19. Основы оперативно-разыскной деятельности : учебное пособие.; под ред. А.Е. Чечетина. 3-е изд., доп. и перераб. Барнаул : Барнаульский юридический институт МВД России, 2007. 236 с.

20. Стрельцов Л.Є. Поняття та ознаки комп'ютерної програми у міжнародному праві. Науковий вісник Міжнародного гуманітарного університету. 2014. Вип. 11 (2). С. 168-171.

21. Шитий С.І., Огороднікова І.І. Особливості порушення прав людини шляхом незаконного використання програмних засобів негласного зняття інформації. Наукові записки Інституту законодавства Верховної Ради України. 2017. № 1. С. 82-92.

22. Возний В.І. Деякі аспекти предмета злочину, передбаченого ст. 359 кримінального кодексу України. Науково-інформачійний вісник. Право. 2013. № 7. С. 248-252

23. Деякі питання щодо спеціальних технічних засобів для зняття інформації з каналів зв'язку та інших технічних засобів негласного отримання інформації : постанова Кабінету Міністрів України від 22 вересня 2016 р. № 699. Офіційний вісник України. 2016. № 79. Ст. 2640.

24. Козенко 0.0. Спеціальна техніка під час проведення досудового розслідування, оперативно-розшукових і контррозвідувальних заходів. Науковий вісник Ужгородського національного університету. Серія «Право». 2016. Вип. 38. Т. 2. С. 110-114.

Виходець Ю. О., ад’юнкт кафедри кримінального процесу одеського державного університету внутрішніх справ 